\title{
The Role Of Elementary Christian Education Materials Based On 2013 Curriculum And Its Effects On Hosana Galilea Private Elementary School Students' Achievements
}

\author{
Benyamin Sitepu M.Pd \\ \{benyamintepu@gmail.com\} \\ Master of Christian Religious Education, Paul Medan High School of Theology
}

\begin{abstract}
Religion has a very important role in human life. Religion becomes a guide in an effort to realize a life that is meaningful, peaceful and dignified. Religious Education is intended to increase spiritual potential and shape students to become human believers and devote to God Almighty and noble as applied in Galilea Hosana Primary School. Christian Religious Education is fundamentally intended to convey good news (evangelion = gospel) which is presented in two aspects, namely the aspect of TRIUNE GOD (GOD THE FATHER, SON , AND HOLY SPIRIT) and his WORK, and the aspect of CHRISTIN VALUES. Based on the above, the role of Christian Religious Education in elementary schools based on 2013 curriculum is very influential in learning achievement in the area of Spiritual Attitude, Social Attitude, Knowledge and Skills. Students in Galilea Hosana Primary School from 2011 to present.
\end{abstract}

Keywords: Christian Education, Curriculum, Student's Acchievements

\section{Introduction}

The 2013 curriculum intends to improve the quality of life and social conditions of the broader Indonesian nation. Therefore the development of the 2013 curriculum is not only related to the issue of the quality of education, but also the quality of life of the Indonesian people in general. The ultimate aim of all learning processes in the implementation of education is to improve the quality of life of students, namely the improvement of good and appropriate knowledge, skills, and attitudes (cognitive, affective, and psychomotor aspects) at school. Thus they are expected to play a role in building social order and a better civilization. Thus, the direction of the implementation of education does not only improve self-quality, but also for a greater interest, namely to build a better quality of life for people, nations, and countries. Thus there is a dimension of improving the personal quality of students. On the other hand there are dimensions of improving the quality of social life. Throughout history, in Indonesia, there have been several curriculum changes, among others are the 976 curriculum; curriculum 94 (KBK); 2006 curriculum (KTSP). The foundation of the 2013 curriculum among others is related to social and community issues; problems that occur in the implementation of education itself.

Learning material occupies a very important position over the whole teaching and learning activities, so it must be prepared in such a way that the implementation of learning can achieve goals that are in accordance with Core Competencies and Basic Competencies. The principles used as the basis for determining learning materials are: 
1. Relevance, Learning material is relevant to the objectives of achieving competency standards and basic competencies.

2. Consistency, Learning material is consistent with the objectives of achieving competency standards and basic competencies.

3. Adequacy, The learning material taught should be sufficient enough to help students master the basic competencies taught

Education is a translation of "education" in English. The word education comes from the Latin "ducere" which means guiding (to lead), plus the prefix "e" which means out. So the basic meaning of education is an action to guide out. According to Lawrence Cremin education is an conscious effort, systematic, and continuous to regenerate, uplifting or obtaining either knowledge, attitudes, values, skills, or sensitivities, as well as any results from the effort. For this reason education must be a top priority in building a better nation of Indonesia in the future, while there is still a chance not to give up learning, the greater the opportunity for this nation to experience accelerated development in accordance with the needs of the curriculum so that today's generation is ready to be educated and also ready to educate. The author receives, considers, and performs and distributes to students positive things from the development of the Christian Religious Education Material for the 2013 curriculum based Hosana Private Galilee primary school on learning achievement which has increased from 2011 to the present. This has experienced greater growth in the Spiritual Attitudes, Social Attitudes, Knowledge, and Skills of students.

\section{Research Methods}

\subsection{Place and time of research}

This research was conducted at the Hosana SDS Galilea Medan. The researcher chose the place as a research location because of its conveniently accessed location. The time for conducting the study began in February 2019 which in practice, begins with the preparation of all administration, teaching materials (Syllabus) and collecting research data.

\subsection{Population and Samples}

The research population according to Suharsimi is the overall subject of the study. Sutrisno Hadi stated that the research population is all individuals who would be the target of generalization and samples to be taken in a study. The population in this study were grade IV, V, VI Galilea Hosana primary school students consisting of three Christian religious education classes. The sample studied came from 30 Christian students from the three classes.

\subsection{Research design}

The research method in this study is experimental research with a quantitative approach. As stated by Mohammad Ali: "Quasi experiments are almost the same as actual experiments, the difference lies in the use of the subject, namely quasi-experiments are not random assignments, but by using existing classes". In this study there are two variables, namely the independent variable and the dependent variable. The independent variables are Learning Achievement on Spiritual Attitudes, Social Attitudes, Knowledge, and Skills of Students, while the dependent variable in this study is the 2013 Curriculum Based Elementary School Application of 2013 to students in grades IV, V, and VI 


\subsection{Data Analysis of Research Results}

In this study data collection was conducted with four different types of questionnaires. This is based on the number of problem formulated that correlate with the research hypothesis so that data can be obtained in measuring each independent variable and its effect on the dependent variable. This is very important in obtaining maximum results in the process of analyzing research dat

Table 1. Cumulative Recapitulation Table of Research

\begin{tabular}{clcccc}
\hline No. & \multicolumn{1}{c}{ Nama } & Pre-test 1 & Pre-test 2 & Pre-test 3 & Pre-test 4 \\
\hline $\mathbf{1}$ & Gabriel Tio H & 75 & 54 & 66 & 64 \\
$\mathbf{2}$ & Christian Joren & 61 & 69 & 77 & 80 \\
$\mathbf{3}$ & Tevy Ulani S. & 96 & 72 & 60 & 58 \\
$\mathbf{4}$ & Adriel Siebert & 39 & 69 & 58 & 64 \\
$\mathbf{5}$ & Ian Demak Steven & 75 & 65 & 58 & 68 \\
$\mathbf{6}$ & Hardi Febrianto & 75 & 75 & 56 & 66 \\
$\mathbf{7}$ & Yossie Beatrice & 75 & 75 & 62 & 69 \\
$\mathbf{8}$ & Natasya Br Ginting & 52 & 82 & 65 & 78 \\
$\mathbf{9}$ & Erpha Praditya & 78 & 71 & 67 & 90 \\
$\mathbf{1 0}$ & Agree Brahmana & 78 & 75 & 58 & 70 \\
$\mathbf{1 1}$ & Kevin Christian M & 75 & 75 & 69 & 59 \\
$\mathbf{1 2}$ & Indah Sijabat & 75 & 69 & 71 & 67 \\
$\mathbf{1 3}$ & Franklin N & 75 & 71 & 62 & 84 \\
$\mathbf{1 4}$ & Juan Paul Arganata & 87 & 103 & 78 & 86 \\
$\mathbf{1 5}$ & Gery Raplyande P & 89 & 65 & 66 & 55 \\
$\mathbf{1 6}$ & Charine Febina T & 75 & 61 & 61 & 64 \\
$\mathbf{1 7}$ & Mario Juan F & 50 & 69 & 100 & 66 \\
$\mathbf{1 8}$ & Grace Imeilda & 75 & 66 & 85 & 82 \\
$\mathbf{1 9}$ & Diandra Brama B & 77 & 66 & 100 & 65 \\
$\mathbf{2 0}$ & Kathryn Octavia M & 75 & 75 & 68 & 76 \\
$\mathbf{2 1}$ & Putri Anlia & 83 & 65 & 71 & 100 \\
$\mathbf{2 2}$ & Zefanya Purba & 75 & 72 & 89 & 80 \\
$\mathbf{2 3}$ & Jeremy Tonggo & 89 & 100 & 70 & 64 \\
$\mathbf{2 4}$ & Novita Gloria S & 75 & 82 & 88 & 73 \\
$\mathbf{2 5}$ & Astri Fanesa P & 50 & 75 & 68 & 68 \\
$\mathbf{2 6}$ & Adendra Denmas & 50 & 70 & 78 & 98 \\
$\mathbf{2 7}$ & Juwita Riris & 85 & 70 & 75 & 65 \\
$\mathbf{2 8}$ & Monica Helena T & 75 & 70 & 90 & 73 \\
$\mathbf{2 9}$ & Ronauli Nirma T & 70 & 68 & 70 & 68 \\
$\mathbf{3 0}$ & Gabriel Sibuea & 75 & 70 & 92 & 80 \\
& Total & $\mathbf{2 1 6 7}$ & $\mathbf{2 1 7 3}$ & $\mathbf{2 1 7 8}$ & $\mathbf{2 1 8 0}$ \\
& Rat-rata & $\mathbf{7 2 . 2 3}$ & $\mathbf{7 2 . 4 3}$ & $\mathbf{7 2 . 6}$ & $\mathbf{7 2 . 6 6}$ \\
\hline & & & & & \\
& & & & & \\
\end{tabular}

Table 2. Cumulative Recapitulation Table of Research

\begin{tabular}{clcccc}
\hline No. & \multicolumn{1}{c}{ Nama } & Post-test 1 & Post-test 2 & Post-test 3 & Post-test 4 \\
\hline & & & & & \\
$\mathbf{1}$ & Gabriel Tio Hilman & 100 & 93 & 100 & 100 \\
$\mathbf{2}$ & Christian Joren & 93 & 95 & 93 & 100 \\
$\mathbf{3}$ & Tevy Ulani S. & 96 & 96 & 94 & 71 \\
$\mathbf{4}$ & Adriel Siebert & 100 & 96 & 92 & 90 \\
$\mathbf{5}$ & Ian Demak Steven & 75 & 75 & 75 & 75 \\
\hline
\end{tabular}




\begin{tabular}{clcccc}
\hline No. & \multicolumn{1}{c}{ Nama } & Post-test 1 & Post-test 2 & Post-test 3 & Post-test 4 \\
\hline $\mathbf{6}$ & Hardi Febrianto & 75 & 75 & 75 & 75 \\
$\mathbf{7}$ & Yossie Beatrice & 75 & 75 & 75 & 75 \\
$\mathbf{8}$ & Natasya Br Ginting & 100 & 96 & 95 & 94 \\
$\mathbf{9}$ & Erpha Praditya & 100 & 100 & 92 & 100 \\
$\mathbf{1 0}$ & Agree Brahmana & 75 & 75 & 75 & 75 \\
$\mathbf{1 1}$ & Kevin Christian M & 75 & 75 & 75 & 75 \\
$\mathbf{1 2}$ & Indah Sijabat & 75 & 75 & 75 & 75 \\
$\mathbf{1 3}$ & Franklin N & 97 & 96 & 92 & 90 \\
$\mathbf{1 4}$ & Juan Paul Arganata & 93 & 100 & 100 & 100 \\
$\mathbf{1 5}$ & Gery Raplyande P & 75 & 75 & 75 & 75 \\
$\mathbf{1 6}$ & Charine Febina T & 75 & 75 & 75 & 75 \\
$\mathbf{1 7}$ & Mario Juan F & 75 & 75 & 75 & 75 \\
$\mathbf{1 8}$ & Grace Imeilda & 97 & 96 & 95 & 96 \\
$\mathbf{1 9}$ & Diandra Brama B & 75 & 75 & 75 & 100 \\
$\mathbf{2 0}$ & Kathryn Octavia M & 96 & 100 & 100 & 100 \\
$\mathbf{2 1}$ & Putri Anlia & 75 & 75 & 100 & 100 \\
$\mathbf{2 2}$ & Zefanya Purba & 89 & 100 & 93 & 100 \\
$\mathbf{2 3}$ & Jeremy Tonggo & 75 & 75 & 75 & 75 \\
$\mathbf{2 4}$ & Novita Gloria S & 100 & 96 & 100 & 100 \\
$\mathbf{2 5}$ & Astri Fanesa Pinem & 75 & 75 & 75 & 75 \\
$\mathbf{2 6}$ & Adendra Denmas & 100 & 100 & 100 & 100 \\
$\mathbf{2 7}$ & Juwita Riris & 75 & 75 & 100 & 100 \\
$\mathbf{2 8}$ & Monica Helena T & 100 & 90 & 100 & 100 \\
$\mathbf{2 9}$ & Ronauli Nirma T & 75 & 100 & 75 & 75 \\
$\mathbf{3 0}$ & Gabriel Sibuea & 100 & 100 & 100 & 100 \\
& Total & $\mathbf{2 5 8 6}$ & $\mathbf{2 6 0 4}$ & $\mathbf{2 6 2 1}$ & $\mathbf{2 6 5 6}$ \\
& Rat-rata & $\mathbf{8 6 . 2 0}$ & $\mathbf{8 6 . 8 0}$ & $\mathbf{8 7 . 3 6}$ & $\mathbf{8 8 . 5 3}$ \\
\hline
\end{tabular}

From the table above it can be seen that there has been an increase in the acquisition of the cumulative score in each test conducted. To be able to better understand the pattern of improvement that occurs for each test carried out, it can be seen in the following graph:

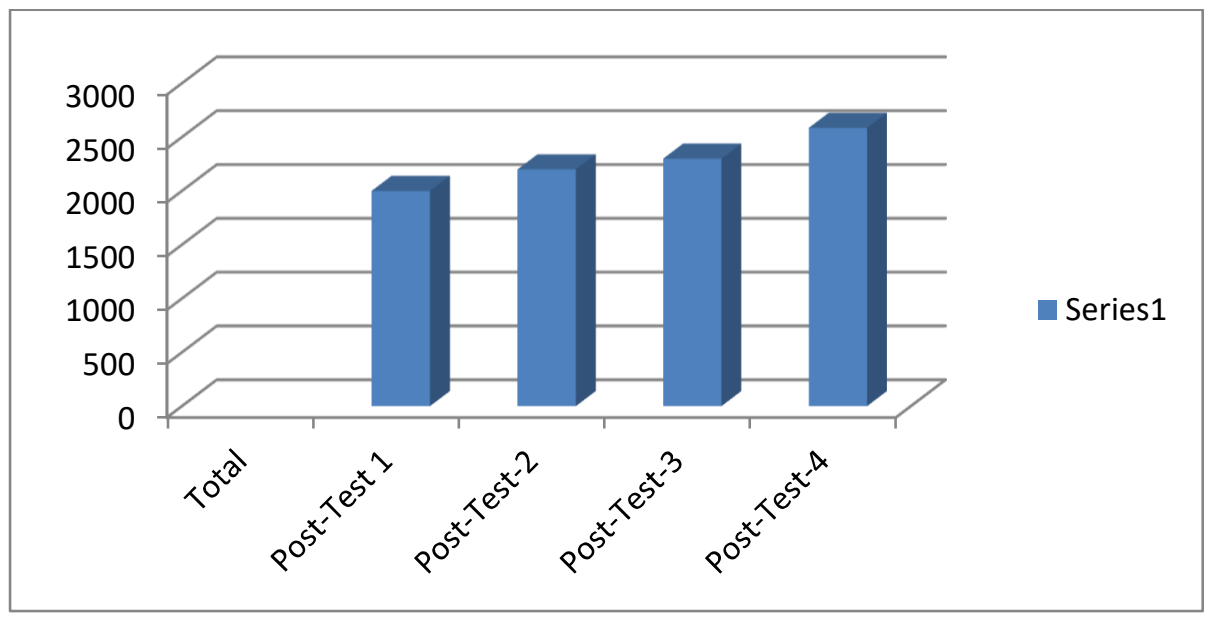

Fig.1. Graph of Recapitulation of Cumulative Score of Research 


\section{Results and Discussion}

In this study the important aspects that are the focus of the study are related to the role of the 2013 Curriculum-based Elementary School Elementary School material on student achievement in Galilea Hosana primary school, in this case students who become objects of research and target of the 2013 curriculum. Therefore, based on the results of the pre-test 1-4 in the data collection research, it can be seen from the analysis of data through the Cumulative Recapitulation Tables and Graphs of Pre-Test Research with an average of 72.25, while based on the results of 1-4 post-tests in collection research Data it can be seen from the analysis of data through Tables and Graphs of Cumulative Recapitulation of Pre-Test Research with an average of 87.00 which is oriented to the collection of research data that provides maximum input with the title "Very Good" in the data analysis process.

\section{Conclusion}

The researcher reassures that the role of the Christian Religious education material in 2013 curriculum-based primary schools had a profound effect on Student Achievements in Spiritual Attitudes, Social Attitudes, Knowledge and Skills in Medan Hosana Galilee primary school. The author hopes that teachers considers the present and the future so that they will continue to play an active role in maintaining, caring for and educating generations who fear God, loving others and having an impact on everyone. A message to all teachers and students "Opportunities will always be for people who always try, and people who are always trying to get the next opportunity "

\section{References}

[1] Homrighausen dan Enklaar, Pendidikan Agama Kristen, (Jakarta : BPK Gunung Mulia, 1999),

[2] Sijabat. BS, Mengajar Secara Profesional, (Bandung: Yayasan Kalam Hidup),

[3] Suharsimi Arikunto, Prosedur Penelitian Suatu Pendekatan Praktik, (Jakarta: Rineka Cipta, 1998),

[4] Sutrisno Hadi, Metodologi Research, (Yogyakarta: Andi Offset, 1984),

[5] Mohammad Ali, Strategi Penelitian Pendidikan, (Bandung: Angkasa, 1992), 